\title{
The Cover Art
}

When I rst saw a photo of this tearful Tibetan child, I wanted to draw her. There is something of the universal human condition in her beauty and sadness. I have juxtaposed the characters representing Buji, which, I am told, can be translated "free from fear." It is a prayer for all the children of the world.

Phil Horner

\begin{abstract}
About the Artist
Phil Horner \#29992 is a prisoner at New Hampshire State Prison for Men in Concord New Hampshire. This is his second submission to the JPP with his rst being in vol. 14(2).
\end{abstract}

The International Committee On Penal Abolition held it's Eleventh Conference in Hobart, Tasmania, Australia, February 7-11, 2006. Congratulations to all the organizers and hosts: Kat Armstrong, Brett Collins, Kilty O'Gorman \& Blue Eyed Jack, Ian Fraser, Tony Bolt, our lmmaker Russ Herman. See JA@justiceaction.org.au for details. A full discussion of the conference will appear in the next issue of the JPP. Conference participants Brenda Murphy (see this issue) and Phil Scraton (Queen's University, Belfast) agreed to take responsibility for ICOPA XII, which is to be held in Belfast, Northern Ireland, in August of 2008. 